\title{
PENINGKATAN DAYA KELUARAN SEL SURYA DENGAN \\ PENAMBAHAN INTENSITAS BERKAS CAHAYA MATAHARI
}

Oleh:

Budhi Priyanto*

\begin{abstract}
ABSTRAK: Sel surya sebagai penghasil energi listrik dari sinar matahari secara langsung saat ini masih memberikan daya keluaran yang relative kecil. Diperlukan panel sel surya yang luas untuk mendapatkan daya besar. Dilakukan metode meningkatkan daya keluaran sel surya dengan tidak menambah luas permukaan panel sel surya. Peningkatan dilakukan dengan menambahkan perangkat pengumpul berkas sinar matahari dari kumpulan lensa cembung yang disusun secara mendatar. Pengumpul berkas sinar matahari terdiri dari 30 lensa dengan panjang fokus $30 \mathrm{~cm}$. Dengan cara ini didapatkan daya keluaran dari panel sel surya yang digunakan mengalami peningkatan. Pada penelitian ini didapatkan peningkatan daya keluaran dari panel sel surya yang digunakan sebesar $26,67 \%$.
\end{abstract}

Kata Kunci: Sel Surya, Daya Keluaran.

\section{PENDAHULUAN}

Memasuki abad ke-21 ini masyarakat dunia dipusingkan dengan permasalahan energi yang berbasis pada bahan bakar minyak. Bahan bakar minyak semakin meningkat harganya dan persediaannya pada sejumlah negara produsen minyak mulai menipis. Hal ini terjadi juga pada negara kita Republik Indonesia. Konsumsi bahan bakar minyak yang melebihi hasil produksi menyebabkan Indonesia berubah menjadi negara pengimpor minyak. Dari hasil survey secara geofisika jumlah cadangan minyak yang ada didalam perut bumi semakin lama semakin menipis dan suatu saat akan habis. Disamping itu penggunaan bahan bakar minyak secara berlebihan menyebabkan polusi udara meningkat menyebabkan menipisnya lapisan ozon didalam atmosfir dan berpengaruh pada iklim dipermukaan bumi. Melihat hal tersebut sebagian besar negara-negara didunia mengembangkan energi alternatif terutama yang tidak menimbulkan polusi udara dan kerusakan lingkungan. Salah satu energi alternatif tersebut adalah penggunaan sel surya.

Sel surya telah lama digunakan terutama sebagai sumber tenaga pada satelit diluar angkasa yang tidak memungkinkan digunakan listrik konvensional [4,5]. Penggunaan

\footnotetext{
* Teknik Elektro Fakultas Teknik Universitas Muhammadiyah Malang

Email:Budhi@umm.ac.id
} 
dalam skala kecil banyak digunakan pada kalkulator, jam tangan dan lain-lain. Saat ini mulai banyak digunakan sel surya sebagai sumber tenaga pada penerangan jalan raya, pada perlintasan rel kereta api, sumber tenaga listrik rumah tangga pada daerah terpencil, pulaupulau kecil dan pada daerah-daerah yang tidak dapat dijangkau dengan listrik konvensional.

Sel surya memiliki kelebihan-kelebihan untuk tujuan tertentu yang tidak membutuhkan daya yang besar. Misalkan untuk penerangan jalan raya dengan kebutuhan daya 50 watt dapat digunakan sebuah sel surya dengan ukuran $0,25 \mathrm{~m}^{2}$. Semakin besar daya yang dibutuhkan semakin luas pula panel sel surya yang diperlukan [8]. Apabila sebuah rumah tangga memerlukan daya 450 watt maka diperlukan panel sel surya seluas 9 $\mathrm{x} 0,25 \mathrm{~m}^{2}=2,25 \mathrm{~m}^{2}$. Semakin besar daya membutuhkan panel sel surya yang semakin luas pula. Hal ini kurang efektif untuk penggunaan dengan pemakaian tempat yang terbatas dan membutuhkan daya yang besar. Melihat hal tersebut muncul pemikiran bagaimana meningkatkan daya keluaran sel surya dengan luas panel tetap tetapi daya yang dihasilkan lebih besar dari sebelumnya.

Sel surya bekerja dengan prinsip efek fotolistrik yaitu sebuah materi akan melepaskan elektron apabila permukaan materi tersebut terkena pancaran cahaya [4,5,7]. Energi elektron yang terlepas dari materi tersebut sangat bergantung pada energi cahaya yang menyinarinya sedangkan jumlah elektron yang terlepas tidak bergantung pada energi tersebut tetapi bergantung pada intensitas cahaya yang menyinari permukaan materi tersebut $[1,6]$. Semakin besar intensitas cahaya yang menyinari semakin besar jumlah elektron yang terlepas dari materi. Jumlah elektron yang terlepas menentukan besarnya arus yang dihasilkan. Semakin besar arus yang dihasilkan semakin besar pula daya yang dihasilkan. Hal ini menunjukkan bahwa semakin besar intensitas cahaya yang menyinari permukaan sel surya mengakibatkan semakin besar pula daya yang dihasilkan oleh sel surya tersebut. Maka penulis membuat penelitian dengan judul " Peningkatan daya keluaran sel surya dengan penambahan intensitas berkas cahaya matahari” [4].

Intensitas cahaya matahari yang menyinari permukaan bumi mempunyai nilai tertentu sesuai letak permukaan bumi tersebut [6]. Bagaimana meningkatkan intensitas matahari yang diterima oleh permukaan sel surya? Pada penelitian terdahulu yang dilakukan penulis dengan judul "panas yang dikumpulkan oleh lensa cembung" pada tahu 1999 menunjukkan bahwa berkas yang dikumpulkan oleh lensa cembung menunjukkan 
peningkatan intensitas yang besar. Melihat hal tersebut lensa cembung dapat digunakan untuk meningkatkan intensitas berkas cahaya [3]. Ada beberapa cara meningkatkan intensitas berkas cahaya matahari yang menyinari permukaan sel surya antara lain: melewatkan berkas cahaya matahari melewati lensa cembung dengan luas permukaan lensa lehih besar dari luas panel sel surya, menambah jumlah sinar matahari yang menyinari permukaan sel surya dengan pantulan dari cermin datar atau cermin cekung. Pada penelitian ini mengunakan media lensa cembung untuk meningkatkan intensitas berkas cahaya matahari yang menyinari permukaan sel surya. Lensa cembung yang tersedia di pasaran mempunyai luas permukaan kecil sehingga sangat sulit untuk menemukan sebuah lensa yang mempunyai luas permukaan lebih besar dari permukaan sel surya. Bagaimana agar didapatkan berkas cahaya matahari yang melewati lensa dengan luas lebih besar dari permukaan panel sel surya? Untuk mengatasi hal tersebut penulis menggunakan kumpulan lensa dengan panjang fokus yang sama disusun membentuk permukaan datar dengan luas yang lebih besar dari luas panel sel surya. Kumpulan lensa cembung disusun secara mendatar ini menambah berkas cahaya matahari yang diterima oleh permukaan panel sel surya $[4,8]$.

\section{HASIL DAN PEMBAHASAN}

Percobaan dilakukan dengan membandingkan daya keluaran dari panel sel surya yang digunakan dengan dua perlakuan yang berbeda pada panel yang sama. Panel sel surya yang digunakan mempunyai spesifikasi sebagai berikut: :[3,8]

$\begin{array}{ll}\text { Jenis } & : \text { Monocristaline silicon solar } \\ \mathrm{P}_{\max } & : 10 \text { watt } \\ \mathrm{V}_{\mathrm{mp}} & : 18 \text { volt } \\ \mathrm{I}_{\mathrm{mp}} & : 0,56 \text { Ampere } \\ \mathrm{V}_{\mathrm{oc}} & : 21,6 \text { volt } \\ \mathrm{I}_{\mathrm{sc}} & : 0,59 \text { Ampere } \\ \mathrm{V}_{\max } \text { system } & : 600 \text { volt }\end{array}$

Size $\quad: 340 \times 280 \times 22 \mathrm{~mm}$

Test condition : Am $5.25^{\circ} \mathrm{C} 1000 \mathrm{~W} / \mathrm{m}^{2}$

Dalam percobaan ini digunakan beberapa peralatan utama yaitu:

1. Avometer digital

2. Lensa cembung panjang focus $30 \mathrm{~cm}$ sebanyak 30 buah

3. Kerangka penyangga 
4. Stop wacth

Percobaan pertama dilakukan dengan melakukan pengukuran daya keluaran dari panel sel surya secara langsung. Pengukuran dimulai pada pukul 10.00 dan pengukuran daya keluaran dilakukan dalam rentang 30 menit. Pengamatan dilakukan dalam 5 hari yang berbeda dengan keadaan cuaca cerah. Pengamatan dengan metode ini diperlihatkan pada gambar 1.

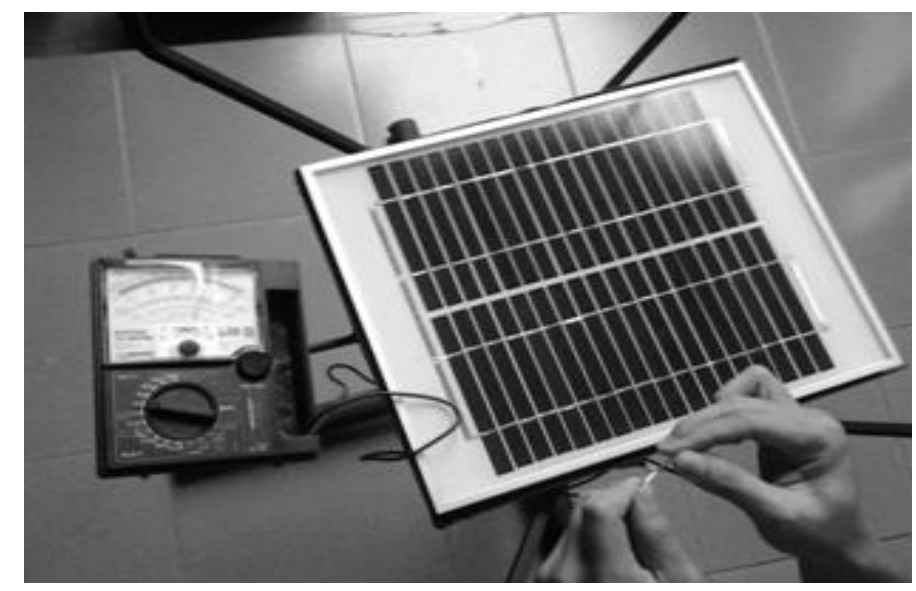

Gambar 1. Pengukuran daya secara langsung

Percobaan kedua dilakukan dengan cara menambahkan kumpulan 30 lensa dengan focus $30 \mathrm{~cm}$ disusun secara mendatar. Panel sel surya diletakkan di bawah kumpulan lensa tersebut dengan jarak $15 \mathrm{~cm}$. Kumpulan lensa di gunakan untuk menambah intensitas cahaya matahari yang diterima oleh panel sel surya. Dengan cara yang sama pengamatan dilakukan selama 5 hari pada kondisi cuaca cerah dan dimulai pada pukul 10.00 dan pengukuran dilakukan setiap selang waktu 30 menit. Susunan percobaan ini diperlihatkan pada gambar $2[3,8]$.

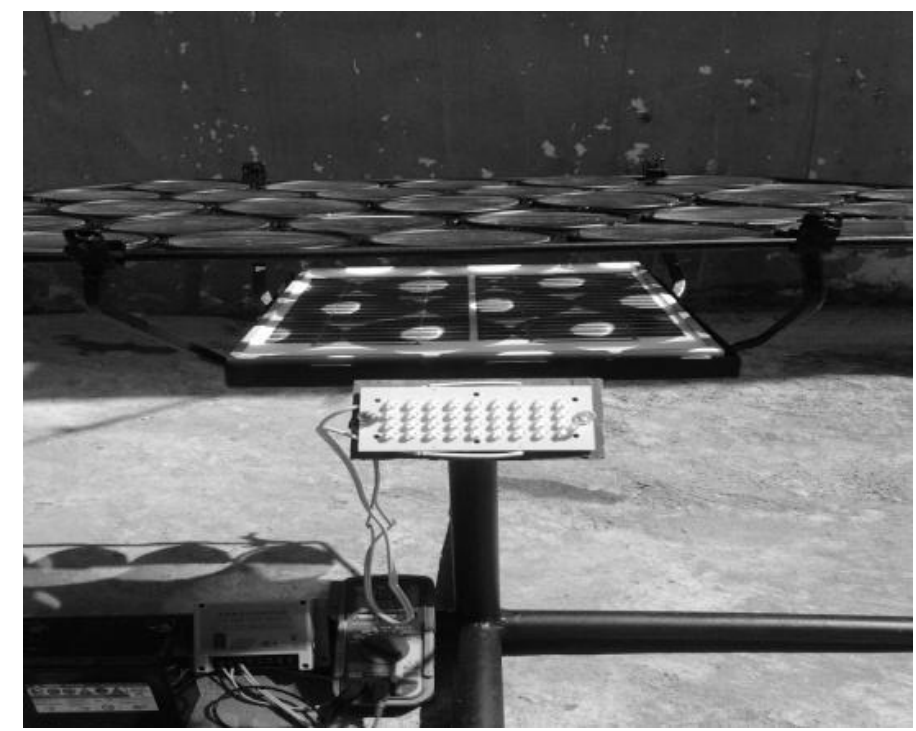

Gambar 2. Pengukuran daya setelah melalui lensa 
Dari hasil pengukuran dua metode yang digunakan didapatkan data sebagai berikut:

\section{Pengukuran hari pertama}

Hasil pengukuran diperlihatkan pada tabel 1.

Tabel 1. Pengukuran hari ke-1

\begin{tabular}{|c|c|c|c|}
\hline No & Jam & $\begin{array}{c}\text { Daya tanpa menggunakan } \\
\text { lensa cembung }\end{array}$ & $\begin{array}{c}\text { Daya menggunakan } \\
\text { lensa cembung }\end{array}$ \\
\hline 1. & $10.00-10.30$ & $5,53 \mathrm{~W}$ & $9,48 \mathrm{~W}$ \\
\hline 2. & $10.30-11.00$ & $6,48 \mathrm{~W}$ & $9,87 \mathrm{~W}$ \\
\hline 3. & $11.00-11.30$ & $7,32 \mathrm{~W}$ & $10,14 \mathrm{~W}$ \\
\hline 4. & $11.30-12.00$ & $8,03 \mathrm{~W}$ & $11,42 \mathrm{~W}$ \\
\hline 5. & $12.00-12.30$ & $8,94 \mathrm{~W}$ & $12,14 \mathrm{~W}$ \\
\hline 6. & $12.30-13.00$ & $9,29 \mathrm{~W}$ & $12,76 \mathrm{~W}$ \\
\hline
\end{tabular}

Grafik hubungan antara waktu penyinaran dengan daya keluaran dari 2 metode yang digunakan ditunjukkan pada grafik 1 .

Grafik Perbandingan Hari 1

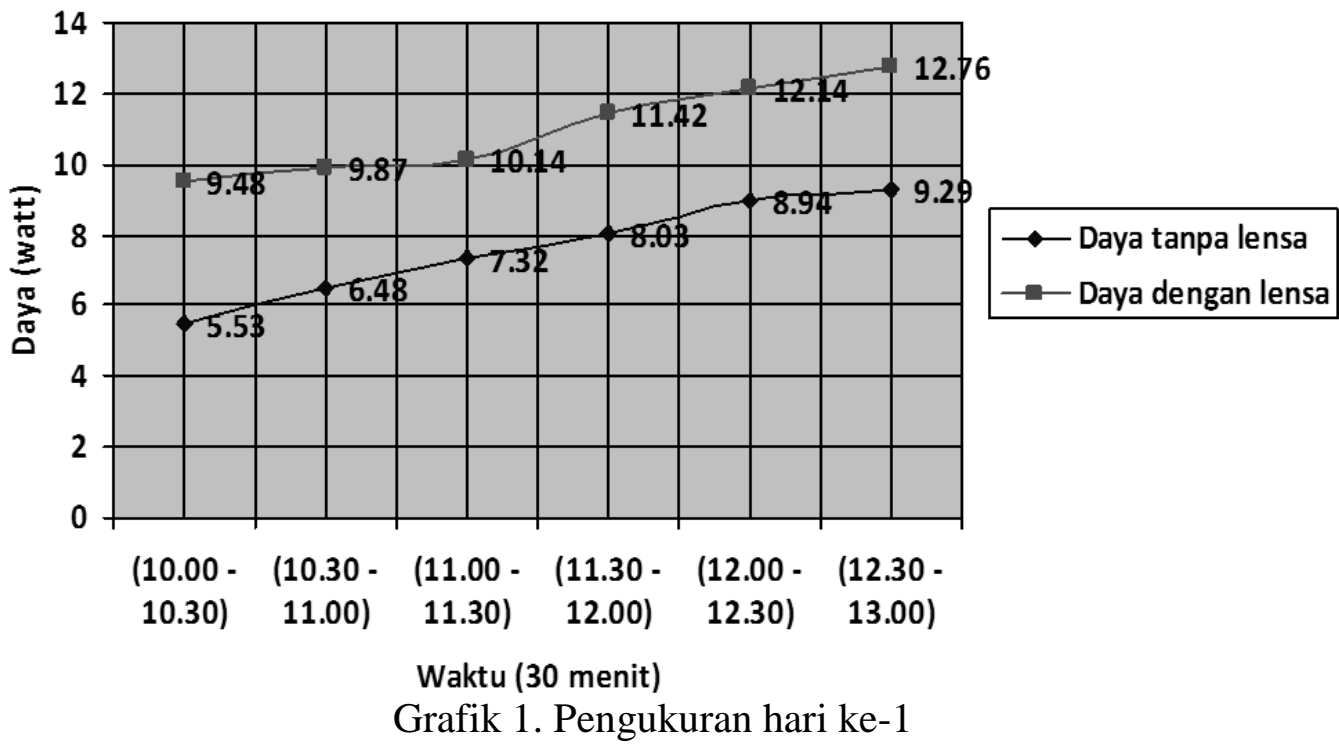

\section{Pengukuran hari kedua}

Hasil pengukuran hari diperlihatkan pada tabel 2. 
Tabel 2. Pengukuran hari ke-2

\begin{tabular}{|c|c|c|c|}
\hline No & Jam & $\begin{array}{c}\text { Daya tanpa menggunakan } \\
\text { lensa cembung }\end{array}$ & $\begin{array}{c}\text { menggunakan } \\
\text { lensa cembung }\end{array}$ \\
\hline 1. & $10.00-10.30$ & $5,70 \mathrm{~W}$ & $8,31 \mathrm{~W}$ \\
\hline 2. & $10.30-11.00$ & $5,93 \mathrm{~W}$ & $9,02 \mathrm{~W}$ \\
\hline 3. & $11.00-11.30$ & $6,92 \mathrm{~W}$ & $9,59 \mathrm{~W}$ \\
\hline 4. & $11.30-12.00$ & $7,83 \mathrm{~W}$ & $9,90 \mathrm{~W}$ \\
\hline 5. & $12.00-12.30$ & $8,54 \mathrm{~W}$ & $11,16 \mathrm{~W}$ \\
\hline 6. & $12.30-13.00$ & $9,02 \mathrm{~W}$ & $12,08 \mathrm{~W}$ \\
\hline
\end{tabular}

Grafik hubungan antara daya keluaran dan waktu penyinaran diperlihatkan pada grafik 2.

\section{Grafik Perbandingan Hari 2}

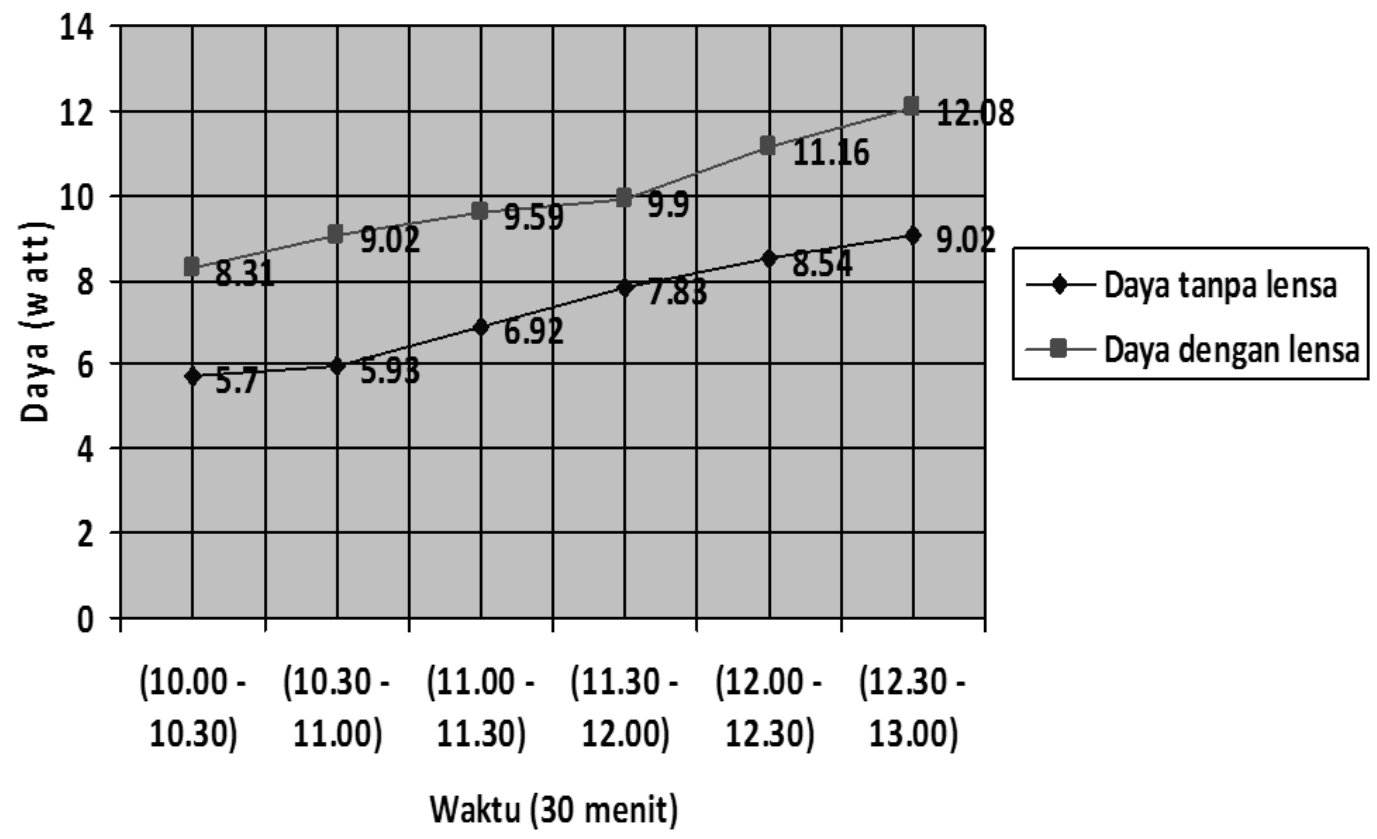

Grafik 2. Pengukuran hari ke-2

\section{Pengukuran hari ketiga}

Hasil pengukuran diperlihatkan pada tabel 3. 
Tabel 3. Pengukuran hari ke-3

\begin{tabular}{|c|c|c|c|}
\hline No & Jam & $\begin{array}{c}\text { Daya tanpa menggunakan } \\
\text { lensa cembung }\end{array}$ & $\begin{array}{c}\text { Daya menggunakan } \\
\text { lensa cembung }\end{array}$ \\
\hline 1. & $10.00-10.30$ & $6,15 \mathrm{~W}$ & $8,58 \mathrm{~W}$ \\
\hline 2. & $10.30-11.00$ & $6,54 \mathrm{~W}$ & $8,85 \mathrm{~W}$ \\
\hline 3. & $11.00-11.30$ & $7,12 \mathrm{~W}$ & $9,23 \mathrm{~W}$ \\
\hline 4. & $11.30-12.00$ & $8,50 \mathrm{~W}$ & $9,79 \mathrm{~W}$ \\
\hline 5. & $12.00-12.30$ & $8,84 \mathrm{~W}$ & $10,31 \mathrm{~W}$ \\
\hline 6. & $12.30-13.00$ & $9,50 \mathrm{~W}$ & $10,74 \mathrm{~W}$ \\
\hline
\end{tabular}

Grafik hubungan antara daya keluaran dan waktu penyinaran diperlihatkan pada grafik 3 .

\section{Grafik Perbandingan Hari 3}

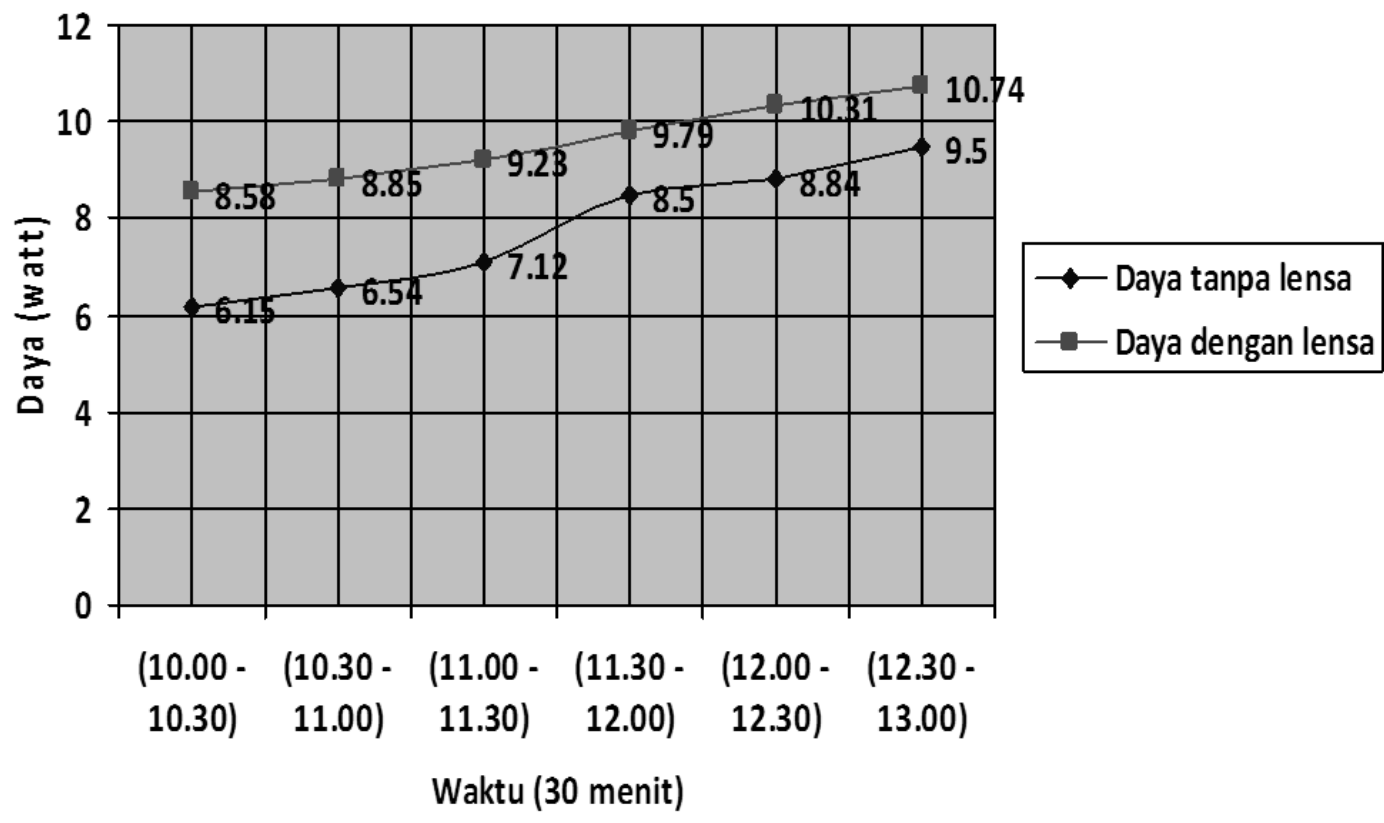

Grafik 3. Pengukuran hari ke-3

\section{Pengukuran pada hari keempat}

Hasil pengukuran diperlihatkan pada tabel 4. 
Tabel 4. Pengukuran hari ke-4

\begin{tabular}{|c|c|c|c|}
\hline No & Jam & $\begin{array}{c}\text { Daya tanpa menggunakan } \\
\text { lensa cembung }\end{array}$ & $\begin{array}{c}\text { Daya menggunakan } \\
\text { lensa cembung }\end{array}$ \\
\hline 1. & $10.00-10.30$ & $5,98 \mathrm{~W}$ & $8,67 \mathrm{~W}$ \\
\hline 2. & $10.30-11.00$ & $7,31 \mathrm{~W}$ & $8,97 \mathrm{~W}$ \\
\hline 3. & $11.00-11.30$ & $8,05 \mathrm{~W}$ & $10,09 \mathrm{~W}$ \\
\hline 4. & $11.30-12.00$ & $8,92 \mathrm{~W}$ & $11,86 \mathrm{~W}$ \\
\hline 5. & $12.00-12.30$ & $9,34 \mathrm{~W}$ & $12,52 \mathrm{~W}$ \\
\hline 6. & $12.30-13.00$ & $9,87 \mathrm{~W}$ & \\
\hline
\end{tabular}

Grafik hubungan antara daya keluaran dan waktu penyinaran pada hari keempat diperlihatkan pada grafik 4 .

\section{Grafik Perbandingan Hari 4}

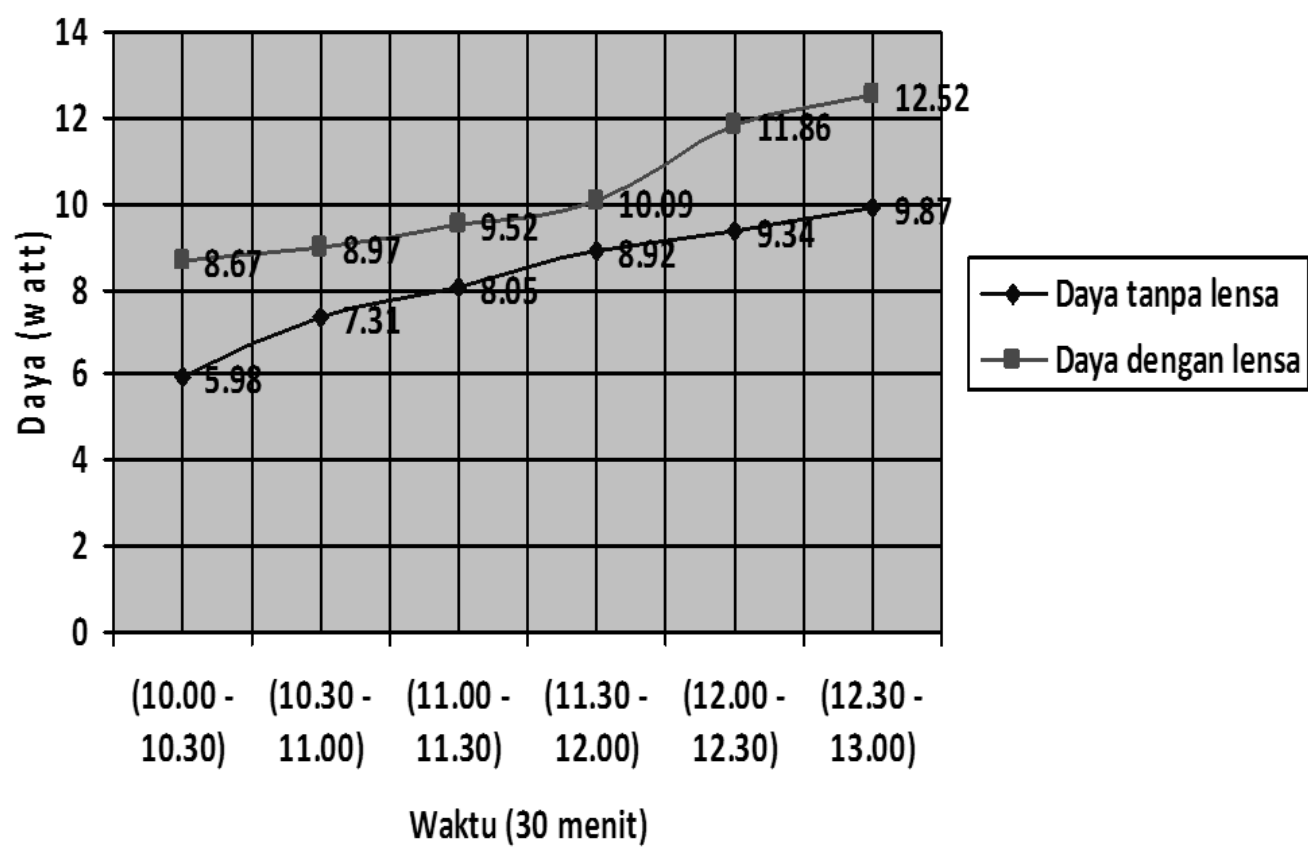

Grafik 4. Pengukuran hari ke-4

\section{Pengukuran hari kelima}

Hasil pengukuran diperlihatkan pada tabel 5. 
Tabel 5. Pengukuran hari ke-5

\begin{tabular}{|c|c|c|c|}
\hline No & Jam & $\begin{array}{c}\text { Daya tanpa menggunakan } \\
\text { lensa cembung }\end{array}$ & $\begin{array}{c}\text { Daya menggunakan } \\
\text { lensa cembung }\end{array}$ \\
\hline 1. & $10.00-10.30$ & $6,15 \mathrm{~W}$ & $8,11 \mathrm{~W}$ \\
\hline 2. & $10.30-11.00$ & $6,34 \mathrm{~W}$ & $8,64 \mathrm{~W}$ \\
\hline 3. & $11.00-11.30$ & $7,68 \mathrm{~W}$ & $8,94 \mathrm{~W}$ \\
\hline 4. & $11.30-12.00$ & $8,75 \mathrm{~W}$ & $10,32 \mathrm{~W}$ \\
\hline 5. & $12.00-12.30$ & $8,98 \mathrm{~W}$ & $11,62 \mathrm{~W}$ \\
\hline 6. & $12.30-13.00$ & $9,63 \mathrm{~W}$ & \\
\hline
\end{tabular}

Grafik hubungan antara daya keluaran dan waktu penyinaran hari kelima diperlihatkan pada grafik 5 .

\section{Grafik Perbandingan Hari 5}

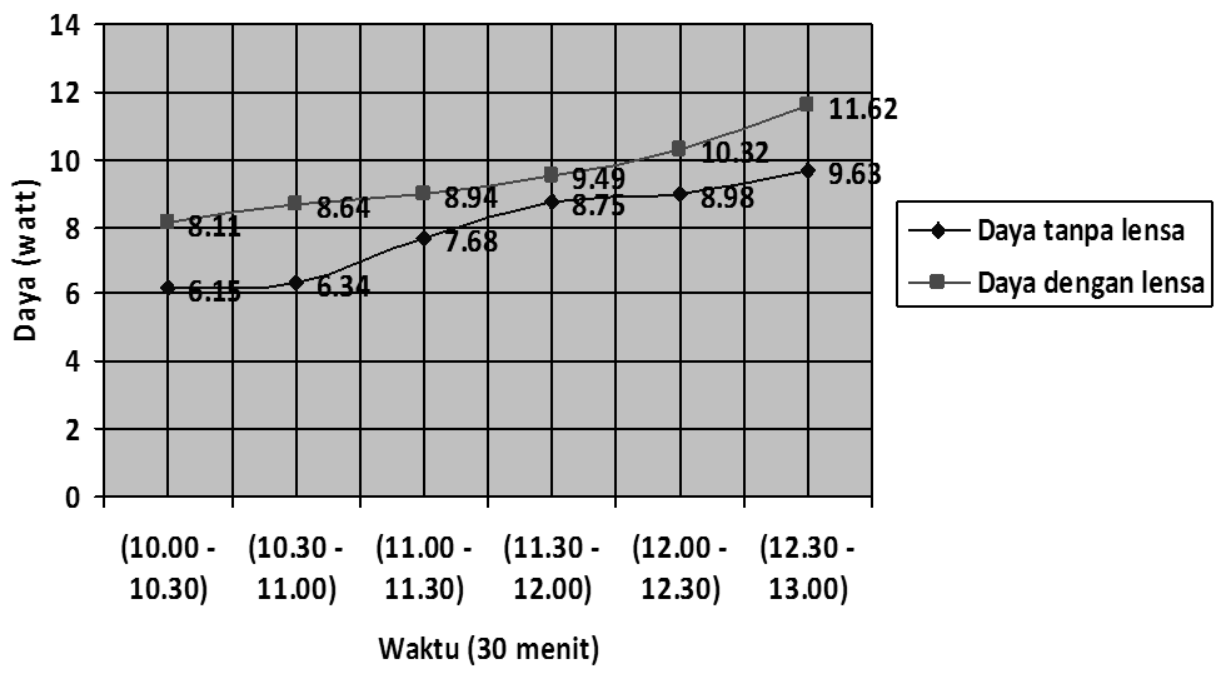

Grafik 5. Pengukuran hari ke-5

Dari grafik 1 sampai grafik 5 pengukuran tanpa menggunakan lensa diperlihatkan oleh garis berwarna biru terlihat bahwa daya keluaran dari sel surya meningkat dengan naiknya waktu pengukuran. Pengukuran yang dilakukan pada pukul 10.00 menghasilkan daya keluaran yang rendah dan daya keluaran meningkat dengan bertambahnya waktu penyinaran. Hal ini menunjukkan kenaikan intensitas cahaya berakibat meningkatnya daya 
keluaran sel surya. Peningkatan daya keluaran berbanding lurus dengan intensitas cahaya yang ditunjukkan dengan grafik cenderung berbentuk linier yang berbentuk linier. Penggunaan lensa cembung yang berfungsi menaikkan intensitas cahaya pada grafik 1 sampai grafik 5 diperlihatkan oleh garis berwarna merah menunjukkan bahwa daya keluaran sel surya meningkat dibandingkan saat berkas cahaya matahari tidak dilewatkan pada lensa. Daya keluaran dari sel surya meningkat seiring dengan peningkatan waktu penyinaran. Perbandingan grafik daya keluaran sel surya antara berkas cahaya diterima langsung oleh sel surya dengan dilewatkan terlebih dahulu melalui lensa menunjukkan gambar yang identik. Hal ini menunjukkan pemakaian lensa tidak mengubah karakteristik sel surya tetapi meningkatkan daya keluaran dari sel surya tersebut [3].

\section{KESIMPULAN}

Dari hasil pengamatan dan analisa dapat disimpulkan:

1. Daya keluaran sel surya meningkat dengan bertambahnya waktu penyinaran dan didapatkan hubungan yang linier.

2. Daya keluaran sel surya meningkat seiring dengan bertambahnya intensitas berkas cahaya matahari yang menumbuk permukaan sel surya dan didapatkan hubungan yang linier.

3. Pemakaian lensa cembung untuk meningkatkan intensitas cahaya berkas sinar matahari meningkatkan daya keluaran sel surya.

4. Pemakaian 30 buah lensa cembung dengan fokus $30 \mathrm{~cm}$ dan panel sel surya diletakkan pada jarak $15 \mathrm{~cm}$ dapat meningkatkan daya keluaran sel surya rata-rata $26,67 \%$.

5. Pemakaian lensa cembung meningkatkan daya keluaran melebihi daya maksimumnya.

\section{DAFTAR PUSTAKA}

[1] Arthur Beiser (The Houw liong, PhD)” Konsep Fisika Modern”, Erlangga 1982

[2] Budhi Priyanto" Pengukuran panas yang dikumpulkan oleh lensa cembung" laporan penelitian UMM 1999

[3] Budhi Priyanto \&Vikko Rosiadi “ Peningkatan daya keluaran sel surya dengan menambah intensitas cahaya melelui lensa cembung" laporan penelitian UMM 2012

[4] Martin A. Green “ Solar Cells” Prentice Hall, 1982 
[5] S.M.Sze " Semoconductor Devices (physics and technology)" John wiley \& sons 1985

[6] Sears \& Zemansky “ Fisika Universitas” Binacipta 1992

[7] Ir. S. Rekario \& Dr. Masamori Iida "Fisika Dan Teknologi Semikonduktor" Pradya Paramita. Jakarta 1982

[8] Vikko Rosiadi "Pengoptimalan solar sel menggunakan lensa cembung" tugas akhir 2012. 